\title{
FILOZOFIA PRAW PODMIOTOWYCH
}

\begin{abstract}
Streszczenie. Prawa podmiotowe (ang. rights) są jednym z czołowych pojęć w anglosaskiej filozofii prawa, filozofii politycznej i etyce. Polski dyskurs filozoficzny zajmuje się najczęściej szczegółowymi problemami lub typami praw podmiotowych (prawa człowieka, prawa konstytucyjne), brakuje natomiast refleksji filozoficznej nad prawami podmiotowymi w ogólności. Refleksję taką można odnaleźć w piśmiennictwie cywilistycznym i konstytucjonalistycznym. W artykule wskazano na różnice w polskim i angielskim dyskursie na temat praw podmiotowych, starano się połączyć różne obszary refleksji nad tymi prawami (w szczególności prawa, etyki i polityki) oraz wskazano na ich filozoficzny potencjał $\mathrm{i}$ zasadnicze kwestie problemowe.
\end{abstract}

Słowa kluczowe: prawa podmiotowe, teoria prawa cywilnego, prawa człowieka, common law, polityka prawa; prawo i moralność, polska teoria prawa, amerykańska teoria prawa.

\section{WPROWADZENIE}

W okresie powojennym rozwój filozofii prawa w Polsce został instytucjonalnie ograniczony i w konsekwencji po roku 1989 refleksja nad wieloma zagadnieniami musiała zostać podjęta na nowo. Jednym z takich obszarów tematycznych są prawa podmiotowe. Okres PRL oznaczał się stonowaniem dyskusji na ich temat, zarówno z powodów ideologicznych (marksizm krytykował ideę praw podmiotowych), jak i politycznych (prawa podmiotowe ograniczały władze państwa). Teoretyczne rozważania dotyczące praw podmiotowych zostały zawężone do badań historycznych, krytyki społeczeństw zachodnich czy dogmatyki cywilistycznej. Powrót praw podmiotowych jako zagadnienia filozoficznego wiąże się z rozwojem dyskusji nad prawami człowieka. Wraz z podpisaniem aktu końcowego Konferencji Bezpieczeństwa i Współpracy w Europie (1975) stały się one kryterium oceny również państw realnego socjalizmu i jednym ze źródeł ich postępującej delegitymizacji (Solomon 2006; Raburski 2012, 154-181).

Po 1989 r. widać rosnące zainteresowanie filozofów poszczególnymi rodzajami praw podmiotowych (prawami człowieka, prawem własności, prawami autorskimi). Czy jednak możemy mówić o czymś takim, jak „filozofia praw podmiotowych"? Brak opracowań ogólnych może sugerować odpowiedź negatywną. Tymczasem w Stanach Zjednoczonych nie można właściwie wydać ogólnej

${ }^{*}$ Uniwersytet im. Adama Mickiewicza w Poznaniu, Instytut Filozofii, Zakład Filozofii Publicznej i Filozofii Prawa, raburski@amu.edu.pl. 
pracy na temat filozofii prawa, filozofii politycznej, etyki, która nie poświęcałaby prawom podmiotowym obszernego fragmentu. Istnieje więc dość szeroki zakres kwestii wspólnych, które dotyczą samej formy, jaką jest prawo podmiotowe, niezależnie od tego, jakie treści ze sobą niesie. Wielu filozofów zajmuje się jedynie tymi prawami, które aspirują do uniwersalności, czyli prawami naturalnymi, prawami człowieka czy prawami podstawowymi, pozostawiając inne poza obszarem refleksji filozoficznej. Inni z kolei, choć podejmują problem praw podmiotowych, to w istocie zajmują się chronionymi przez nie wartościami czy dobrami (np. kwestiami równości, poszczególnymi wolnościami, reprezentacją). Samemu pojęciu „prawa podmiotowego” często nie poświęca się odrębnej uwagi w podręcznikach, leksykonach czy ogólnych pracach teoretycznych ${ }^{1}$. Monografie teoretycznoprawne pojęcia pochodzą sprzed kilku dekad (Opałek 1957; Wronkowska 1973). Najwięcej nośnych filozoficznie treści można współcześnie odnaleźć w pracach cywilistycznych, konstytucjonalistycznych oraz tych poświęconych prawom człowieka².

Artykuł ten ma zarysować obszar filozoficznej refleksji nad prawami podmiotowymi, niezależnie od ich szczegółowych treści. Istotnym problemem jest panujące w tym obszarze zamieszanie pojęciowe, którego, niestety, nie da się uniknąć przez ścisłe definicje, wobec utrwalonego uzusu językowego. Problemy te ulegają nasileniu w wyniku rosnącego, od ponad dwóch dekad, wpływu anglosaskiego piśmiennictwa na polską teorię i filozofię prawa (Wojtczak 2011) Rights są jednym z kluczowych pojęć prawnych, etycznych i politycznych w krajach anglosaskich (Edmundson 2004; Primus 2004; Dworkin 1998; Scheingold 2004; Waldron 1992). Prace autorów wywodzących się z tych kultur prawnych są powszechnie znane i komentowane, a niektóre kluczowe dzieła zostały przethumaczone na język polski ${ }^{4}$. Podstawowa refleksja nad pojęciem prawa podmiotowego jest więc niezbędna nie tylko dla właściwego zrozumienia tych tekstów, lecz także dla współczesnych debat prawnych, politycznych i etycznych.

${ }^{1}$ Na przykład brak opracowania tego pojęcia w: Kowalski, Lamentowicz, Winczorek 1981; Kojder, Cywiński 2014, Zirk-Sadowski 2000, Zajadło 2007. Krótki jego opis dają: Bator 2008, 303-304; Lang, Wróblewski, Zawadzki 1980, 343-345. Niektórzy redaktorzy prac zbiorowych podjęli zagadnienie praw podmiotowych w odrębnych tekstach (Zajadło 2004). Stosunkowo najwięcej na ten temat można znaleźć w pracach wywodzących się ze ,szkoły poznańskiej” (Wronkowska, Ziembiński 2001, 106-113; Ziembiński 1980, 364-373), co jest pewnie rezultatem tego, że pojęciu prawa podmiotowego poświęcona była praca doktorska Sławomiry Wronkowskiej (Wronkowska 1973).

${ }^{2}$ Zob. szczególnie: Pyziak-Szafnicka 2007; Osiatyński 2011. Warto też zwrócić uwagę na niektóre prace administratywistyczne, m.in. Jakimowicz 2002. Zastanawia brak analizy pojęcia w: Stelmachowski 1998.

${ }^{3}$ Jest to dość istotne przesunięcie. Do okresu II wojny światowej polski dyskurs na temat praw podmiotowych był pod dużymi wpływami nauk niemieckiej i francuskiej.

${ }^{4}$ Dworkin 1998; Finnis 2001; Nozick 1999, a także prace autorów niemieckich: Habermas 2005; Alexy 2010. 


\section{KWESTIE POJĘCIOWE}

Jedną z kluczowych kwestii jest definicja prawa podmiotowego, a właściwie trzy związane z nią problemy definicyjne. Pierwszym z nich są spory o definicję prawa podmiotowego $\mathrm{w}$ języku polskim; drugim różnice $\mathrm{w}$ zakresach znaczeniowych polskiego prawa podmiotowego a odpowiednimi pojęciami w innych językach (w szczególności angielskimi rights); trzecim różnice między prawniczymi znaczeniami „prawa podmiotowego" a pojęciami pokrewnymi, używanymi w polityce czy etyce. Dla filozofii praw podmiotowych istotne jest porównanie języka polskiego z językiem angielskim, ponieważ na gruncie tego języka filozofia ta jest obecnie najbardziej rozwinięta.

W prawniczej literaturze polskojęzycznej dominują dwa ujęcia prawa podmiotowego. Zgodnie z pierwszym - prawem podmiotowym jest pewien zespół norm (w szczególności uprawniających czy kompetencyjnych); zgodnie z drugim - prawo podmiotowe jest pewną sytuacją normatywną podmiotu, pewnym „skrótem myślowym” ujmującym różne, niejednorodne normatywnie sytuacje (Pyziak-Szafnicka 2007, 687-713; Wronkowska 1973, 56-67). Na kwestie definicyjne nakłada się sięgający XIX w. spór o istotę prawa podmiotowego, czyli o to, co chronią te prawa. Zgodnie z tzw. teorią woli (Savigny, Windscheid) prawo jest sferą, w której jednostka może w sposób chroniony przejawiać swoją wolę. $\mathrm{Z}$ kolei teoria interesu (Ihering) wskazuje, że u podstaw praw podmiotowych leżą podstawowe interesy jednostek. Współcześnie obie koncepcje są często łączone ${ }^{5}$, spór jest jednak nadal istotny i ma duży potencjał filozoficzny (wynikają z niego np. różnice w koncepcjach praw człowieka) (Wenar 2005, sec. 2.2.2).

Powyższe definicje formułowane są na gruncie prawa. Filozofia praw podmiotowych traktuje jednak to pojęcie szerzej, również z politycznego czy etycznego punktu widzenia. Jeśli ktoś w sferze publicznej mówi, że „ma prawo do uczestnictwa w debacie publicznej”, to najczęściej nie ujmuje tego w kategoriach prawnych, lecz w politycznych - jako pewne roszczenie do uczestnictwa politycznego, ochrony interesów, legitymizacji działań czy wzmocnienie swoich politycznych racji. W etyce natomiast użycie sformułowania „mam prawo” oznacza, że pewne działania są traktowane jako legitymowane etycznie.

Pomiędzy prawniczym, etycznym i politycznym znaczeniem istnieje ścisła łączność. „Prawnicze” prawa podmiotowe to nie jest jakakolwiek „sytuacja prawna podmiotu", lecz sytuacja, która ma pewne oparcie etyczne (nawet jeśli prawnicy tego najczęściej nie zauważają). Etyczne wskazania mogą przekształcać się

${ }^{5}$ Przykładowo, w tej definicji: „Prywatne prawo podmiotowe to powszechnie chronione (uznane) interesy (wartości, dobra), których realizację określają normy prawa, wyznaczając podmiotom prywatnym zakres swobody i wyłączności zachowań w relacjach z innymi uczestnikami obrotu oraz określając środki prawne na wypadek naruszenia lub zagrożenia tych interesów" (Bierć 2012, 98). 
w roszczenia polityczne, a te z kolei mogą być przekształcane w „prawnicze” prawa podmiotowe.

Jeślibyśmy mieli się pokusić o próbę ogólnego ujęcia prawa podmiotowego we wszystkich trzech obszarach, można by je określić jako przysługującą pewnym podmiotom instytucję (najczęściej opartą na uprawnieniu), która pozwala im działać w sferze publicznej w sposób legitymowany (politycznie, etycznie, prawnie) i która może chronić różnorodne dobra czy wartości. Ta forma instytucjonalna jest również pewną forma dyskursywną, czyli formą językowej prezentacji pewnych argumentów czy żądań (prawniczych, etycznych, politycznych).

Takie ujęcie, w ogólnym zarysie, odpowiada też pojęciu right $\mathrm{w}$ języku angielskim (Campbell 2001). Pojęcia te nie są jednak zupełnie tożsame i wiążą się z odmienną siatką skojarzeń semantycznych. Angielskie right jest wieloznaczne w odmienny sposób niż polskie „prawa”. Obok „prawa podmiotowego” oznacza „racje” czy „słuszność”, co powoduje, że o ile polskie prawo podmiotowe jest ściśle związane z dyskursem prawniczym, o tyle angielskie right ma wyraźny wymiar etyczny. Polskie „prawo podmiotowe” jest właściwie prawniczym terminem technicznym, nieznanym szerszemu ogółowi. W użyciu potocznym funkcjonuje „prawo" używane zarówno w sensie przedmiotowym, jak i podmiotowym. Język polski zbliża do siebie te dwa znaczenia, w przeciwieństwie do języka angielskiego, gdzie law i right są wyraźnie odrębne. Bliskość prawa przedmiotowego i podmiotowego jest wzmacniana dominacją pozytywizmu prawniczego, zgodnie z którym jedynymi istotnymi prawami podmiotowymi są te gwarantowane przez stanowione prawo w sensie przedmiotowym. Warto też zauważyć, że istotne w języku angielskim pojęcie legal rights jest w języku polskim pleonazmem i każde jego nieopisowe thumaczenie jest bardzo niezręczne ${ }^{6}$. Mocna teza Benthama, że nie ma innych praw podmiotowych niż właśnie legal rights, jest trudna do wyrażenia w języku polskim.

Pojęcie „prawa podmiotowego" jest właściwie nieznane poza językiem prawniczym. Stąd rights, zadomowione również w języku potocznym, oddawane jest często po prostu jako „prawa” (Dworkin 1998; Hart 1998) lub „uprawnienia" (Finnis 2001). Innym częstym zabiegiem jest stosowanie tych praw zawsze z dookreślającym przymiotnikiem (prawa człowieka, prawa naturalne, prawa konstytucyjne). Takie zabiegi, choć mogą zapewnić pewną stylistyczną spójność przekładu, zacierają autonomię problematyki praw podmiotowych i utrudniają niewprawionemu czytelnikowi jej zrozumienie. Jakikolwiek automatyzm w przekładzie czy ustalanie ścisłych relacji semantycznych są tu niewskazane i mogą prowadzić do nieporozumień. Również angielskie right jest wieloznaczne i nie w każdym przypadku można je tłumaczyć jako „uprawnienie” czy „prawo

${ }^{6}$ Jako „uprawnienia prawne” thumaczy się je w: Dworkin 1998. Inna możliwość, „legalne prawa", jest błędną kalką z angielskiego (tak np. tutaj: http://www.tygodnikplus.com/pl/n426/legalne-prawa-pracownikow, dostęp 20.01.2017). Wydaje się, że najzręczniejszą formą byłyby uprawnienia moralne odróżniane od uprawnień pozytywnych. 
podmiotowe". Na przykład w tekstach Leo Straussa i Erica Voegelina pojawia się pojęcie natural right, niemające jednak znaczenia prawniczego, ale czysto etyczne czy filozoficznopolityczne (Voegelin 1978; Strauss 1983). Nie jest to pojęcie przypisywane podmiotom, lecz używane przedmiotowo - jako coś, co jest z natury słuszne. Natural right trzeba by było więc thumaczyć jako „naturalna słuszność", a nie (jak np. w polskim przekładzie Straussa) jako „uprawnienie” (Strauss 2012). Tłumaczenie tego jako „uprawnienia” czyni tekst niezrozumiałym i ustawia go w zupełnie błędnym kontekście intelektualnym.

\section{RÓŻNORODNOŚĆ PRAW PODMIOTOWYCH}

Prawa podmiotowe mogą być traktowane jako pewna forma instytucji, która może być wypełniana różnymi treściami. Filozofów najczęściej interesowały jedynie te prawa, które są uznawane za najbardziej podstawowe czy zawierające roszczenie do uniwersalności (prawa naturalne, prawa człowieka). Pomijali natomiast „Zwykłe" pozytywne prawa podmiotowe, zawarte w prawie cywilnym czy procesowym. Podmiotowe prawa pozytywne, nie uznawane za podstawowe, cechują się dużą różnorodnością form i wpisane są ściśle w poszczególne gałęzie prawa. Krytycy praw podmiotowych często zwracają się przeciwko pewnemu tylko typowi praw, a nie prawom jako takim ${ }^{7}$. Prawa człowieka mogą być pozytywizowane $\mathrm{w}$ obrębie danego porządku prawnego, np. jako prawa konstytucyjne czy prawa podstawowe. Tracą przez to wiele ze swej sporności i zyskują na praktycznym znaczeniu. Relacje między prawami człowieka a prawami podstawowymi i prawami konstytucyjnymi są skomplikowane, i zależą w dużej mierze od stanowiska konkretnego autora (Przybyszewski 2010, 21-37; Piechowiak 1999).

Innym źródłem różnorodności praw jest zakres podmiotów, którym są przypisywane. Mogą one przysługiwać osobom fizycznym, osobom prawnym (przedsiębiorstwom, organizacjom, państwom), grupom, kategoriom osób (kobietom, homoseksualistom) czy innym bytom kolektywnym (mniejszościom etnicznym, ludom, narodom). Część z tych sporów ma wymiar w dużej mierze praktyczny (komu i na jakich warunkach przypisywać osobowość prawną), zaś część jest przedmiotem zainteresowania filozofów (np. podmiotowość prawna płodów, zwierząt czy nawet całych systemów biologicznych) (Beamish, Neville 2006; Piechowiak 1999).

Ostatnim, zasadniczym źródłem różnorodności praw podmiotowych jest złożoność samej instytucji prawa podmiotowego. Zwykle jest ono określane jako pewna wiązka prostszych elementów, w których dominującą rolę odgrywają różnego typu uprawnienia. Małgorzata Pyziak-Szafnicka wyróżnia kilka typów

${ }^{7}$ Na przykład znana Benthamowska krytyka praw podmiotowych, dotyczyła jedynie praw naturalnych, przeciwstawianych prawom pozytywnym (Bentham 1973). 
uprawnień, które decydują o charakterze praw podmiotowych. Są to uprawnienia władcze, roszczenia, uprawnienia kształtujące oraz zarzuty (Pyziak-Szafnicka 2007, 706-713). Z kolei Sławomira Wronkowska, analizując znaczenia zwrotu „A ma prawo" (co również wskazuje na elementy składowe tej instytucji), wyróżnia: dozwolenia, indyferencję (wolność dwustronna), wolność prawnie chronioną, uprawnienie, kompetencję, immunitet, przywilej i korzystną sytuację.

Taka złożoność instytucji charakteryzuje również angielskie rights, choć siatka semantyczna jest tu nieco inna. W krajach systemu common law fundamentalne znaczenie mają dystynkcje wprowadzone przez Wesleya Newcomba Hohfelda (Hohfeld 1923), który wyróżnił kilka opozycyjnych par podstawowych pojęć prawoznawstwa: uprawnienie (right) i obowiązek (duty), przywilej (privilege) i brak uprawnienia (no-right), kompetencję (power) i podległość kompetencji (liability), immunitet (immunity) oraz brak kompetencji (disability) (Błachut 2002, 35-36). Nowsze opracowania tego schematu traktują go jako klasyfikację typów praw podmiotowych, podstawiając w miejsce Hohfeldowego right-entitlements bądź claim rights (uprawnienia, roszczenia), zaś w miejsce priviledges - liberties (wolności relacyjne, swobody) (Primus 2004, 37; Harel 2005, 193; Osiatyński 2011, 66). Schemat ten jest powszechnie stosowany nie tylko w obszarze prawa, lecz także przez filozofów polityki i etyków (Wenar 2005). Na przykład częsta fraza: „podstawowe prawa i wolności” oznacza w istocie: „prawa podmiotowe w typie uprawnienia i prawa podmiotowe w typie wolności prawnie chronionej”.

Świadomość różnorodności form praw podmiotowych jest kluczowa dla zrozumienia wielu zagadnień prawniczych, etycznych i politycznych. Powinno się je traktować raczej jako pewien ,parasol pojęciowy”, obejmujący podobne do siebie instytucje, aniżeli ściśle zdefiniowane pojęcie podstawowe.

\section{DOKTRYNY POLITYCZNE A PRAWA PODMIOTOWE}

Potocznie uważa się, że prawa podmiotowe mają charakter liberalny. W takiej ogólnej postaci stwierdzenie to, choć nie pozbawione podstaw, jest nieprawdziwe. Rzeczywiście, prawa podmiotowe są jednym z najważniejszych pojęć w języku liberałów i stanowią podstawowy element, z którego budują oni swoją koncepcję sfery publicznej. Liberalny indywidualizm łączy się z wysoką oceną autonomii jednostek oraz ich podmiotowości sprawczej. Prawa podmiotowe są gwarantami tej autonomii i narzędziami w realizacji jednostkowych interesów. Związek pomiędzy prawami i liberalizmem nie jest jednak tak ścisły, jak to się często przedstawia. Prawa podmiotowe nie wywodzą się z liberalizmu i nie muszą być liberalne. Kwestię sporną stanowi natomiast to, czy możliwy jest liberalizm bez praw podmiotowych.

Prawa podmiotowe są obecne w prawie, polityce i filozofii znacznie dłużej niż liberalizm. Narodziny indywidualnych praw podmiotowych można datować 
na XII-XIV w. i konflikty pomiędzy różnymi elementami feudalnego społeczeństwa (Borucka-Arctowa 1957; McGrade 1980; Reid 1998). Prawami podmiotowymi były zarówno boskie prawa królów, jak i stanowe przywileje wywalczone przez możnowładców czy mieszczan. Feudalne spory politycznoprawne były więc konfliktem praw podmiotowych o nieliberalnym charakterze. Zasługą liberalizmu jest natomiast przekształcenie tej wcześniejszej tradycji i uczynienie z praw podmiotowych instrumentów obrony jednostek przeciwko nadużyciom władzy publicznej. Publiczne prawa podmiotowe pozostają koncepcją rzadką i teoretycznie marginalną (Jakimowicz 2002).

W XIX w. zaczęła dominować liberalna idea praw podmiotowych, stąd też opozycja wobec liberalizmu często była wymierzona również w prawa podmiotowe. Bardzo krytycznie wobec praw podmiotowych nastawiony był marksizm, traktując je jako szkodliwe instytucje fasadowe (Marks, Engels 1962). W tym ujęciu prawa podmiotowe tworzyły człowieka egoistycznego, wyobcowanego z życia społecznego i odartego z istotnych składników własnej tożsamości. Były one fałszywą obietnica, gdy tymczasem prawdziwa emancypacja opierać się musi na zmianie materialnej bazy społeczeństwa. Również państwowy marksizm krajów demokracji ludowej nastawiony był negatywnie do indywidualnych praw podmiotowych. Powszechne było przeciwstawianie fałszywych praw podmiotowych - deklarowanych w konstytucjach zachodnich - autentycznym prawom socjalnym krajów socjalistycznych. Prawa te, choć formalnie przysługiwały jednostkom, to roszczenia do ich realizacji były w rękach różnych organów (np. związków zawodowych) (Leżoń 1977). Nie były również odosobnione poglądy, że pojęcie prawa podmiotowego powinno być w ogóle wyeliminowane z języka prawniczego (Opałek 1957).

W przeciwieństwie do marksizmu, lewica socjaldemokratyczna traktowała indywidualne prawa podmiotowe jako ważny instrument reform społecznych. Nie wystarczały jej liberalna równość wobec prawa czy prawa polityczne, lecz poprzez wspieranie praw pracowniczych czy praw socjalnych socjaldemokracja dążyła do stworzenia bardziej sprawiedliwego społeczeństwa. Najpełniejszą postać socjaldemokratycznej teorii praw podmiotowych, a zarazem podstawę polityki i socjologii praw podmiotowych, można znaleźć w powojennych tekstach T. H. Marshalla (Marshall 1997). W latach 60. XX w. walka o prawa obywatelskie grup marginalizowanych (kobiet, Afroamerykanów, homoseksualistów) stała się podstawową formą walki politycznej amerykańskiej lewicy. Sądowe domaganie się realizacji praw podmiotowych było sposobem na oddolną zmianę polityczną i pominięcie skostniałej, niezdolnej do autentycznej zmiany legislatywy (Scheingold 2004; Primus 2004). Amerykańska lewica do dzisiaj traktuje prawa podmiotowe jako podstawowe narzędzie służące reformie społecznej, choć od lat 90. liczne są głosy wskazujące na rozczarowanie ich skutecznością (Rosenberg 1991; Kennedy 1997).

Obok radykalnej lewicy wyraźnie przeciwko prawom podmiotowym wypowiadali się konserwatyści. Amerykańscy konserwatyści występowali przeciwko ruchowi na rzecz praw obywatelskich, rozciagganiu praw politycznych na kolejne grupy 
społeczne, przeciwko prawom socjalnym i reformom społecznym przeprowadzanym przez Sąd Najwyższy ery Warrena. Jednak również oni popierali pewną koncepcję praw podmiotowych, wywodzoną z klasycznego liberalizmu oraz doktryny ojców założycieli, skupioną na wolnościach osobistych i prawie własności. Ruchom abolicjonistycznym, walczącym o prawa niewolników, konserwatyści przeciwstawiali „święte prawo własności” czy „prawa stanów” do zachowania instytucji niewolnictwa wbrew rządowi federalnemu. W ,erze Lochnera” (1905-1937) ustawodawstwo regulujące rynek pracy było utrącane przez Sąd Najwyższy powołujący się na wolności zawierania umów. Nie jest więc prawda, że konserwatystom obca jest idea praw podmiotowych. Cechą charakterystyczną amerykańskiej polityki jest to, że właściwie wszystkie nurty polityczne odwołują się do praw podmiotowych jako podstawy sfery publicznej (Primus 2004; Raburski 2014). Pod koniec XX w. konserwatyzm amerykański z nową energią wkroczył w sferę publiczną, w dużej mierze korzystając z wcześniejszych doświadczeń lewicy i liberalizmu w zakresie „polityki praw” oraz cofając za jej pomocą wiele reform społecznych przeprowadzonych od lat 60. (Coyle 2013; Hilbink 2009). Współczesna amerykańska sfera publiczna stała się w ten sposób obszarem wojen kulturowych prowadzonych za pomocą różnych koncepcji praw podmiotowych (np. spór na temat aborcji toczony jest między zwolennikami „prawa do życia” a zwolennikami „prawa wyboru”, „prawa do autonomii cielesnej” czy ,praw reprodukcyjnych”). Polska i amerykańska tradycja konserwatywna różnią się pod wieloma względami. Wypracowane przez amerykański konserwatyzm metody walki politycznej przy pomocy praw podmiotowych niekoniecznie muszą się przyjąć w Polsce, choć można zauważyć pewne importy dyskursywne, definiujące niektóre spory w kategoriach praw (np. debata o aborcji czy ruch antyszczepionkowy).

\section{ETYKA PRAW PODMIOTOWYCH}

Związek praw podmiotowych z etyką jest bardzo silny. Nie tylko wyrażają one wartości czy normy etyczne, pozwalają formułować istotne etycznie kwestie, lecz także mogą być podstawą pewnego typu teorii etycznej.

Metaetyczna problematyka praw podmiotowych rozwijana jest przede wszystkim w krajach anglosaskich. W polskich tekstach, które są najczęściej tłumaczeniami, widać pewną trudność $\mathrm{w}$ operowaniu tym pojęciem na gruncie etyki (Hołówka 2000,74). Mowa jest w nich o „etyce praw” lub „etyce uprawnień”, same zaś rights oddawane są najczęściej jako „uprawnienia moralne” (Almond 2000; Hołówka 2000, 74 i n.; Brandt 1996, 734-770) ${ }^{8}$. Właściwie wszystkie teksty etyczne poświęcające więcej uwagi prawom pisane są z perspektywy amerykańskiej (książka Jacka Hołówki również przeznaczona była pierwotnie na rynek

\footnotetext{
${ }^{8}$ Czasami w jednej pracy „prawa” i , uprawnienia” stosowane są zamiennie (Vardy, Grosch 1994).
} 
amerykański), tzn. zakładają pewną oczywistość tej tematyki dla czytelnika oraz konteksty znaczeniowe wywodzące się z języka angielskiego.

$\mathrm{W}$ anglosaskich koncepcjach etycznych prawa podmiotowe pojawiają się dość często, pełnią jednak różne funkcje. Najczęściej jest to element czy modyfikacja innych teorii etycznych. Teorie etyczne odwołujące się do praw podmiotowych zakładaja pewien podstawowy katalog praw i stosują charakterystyczną dla praw metodologię (formalizm, proceduralizm) lub słownictwo (np. „roszczenia etyczne").

Najczęściej prawa są jedynie dodatkiem do innych teorii etycznych. Traktuje się je jako swego rodzaju hamulce lub ograniczenia, chroniące autonomię i wolność jednostek przed presją ogółu czy wspólnot. Prawa są np. twardymi ograniczeniami w wielu współczesnych etykach utylitarystycznych, tonując jego radykalne konsekwencje (Hart 2001a; 2001b). W utylitaryzmie zasad są traktowane jako instrumentalne dla globalnej maksymalizacji użyteczności (Wenar 2005). Komunitarianie, zauważając dominację dyskursu praw podmiotowych, starają się znaleźć nową harmonię między wspólnotą (obowiązki) i jednostkami (prawa) (Etzioni 1994). Takie „minimum” praw podmiotowych (najczęściej w postaci praw człowieka) jest standardem przyjętym w wielu współczesnych teoriach etycznych (Rawls 2009; 2001; Nickel 2003).

Teorie etyczne, które starają się całkowicie oprzeć na idei praw podmiotowych jako elemencie konstrukcyjnym, są stosunkowo nieliczne. Pierwszymi spośród nich były etyczne interpretacje teorii praw naturalnych, których wiele powstało od początków ery nowożytnej. W drugiej połowie XX w. pojawiła się jednak idea nowa, zgodnie z którą na moralnych prawach podmiotowych miałby się opierać pewien typ teorii etycznej. Idea takiego typu etyki wywodzi się od Dworkina, który zasugerował podział filozofii politycznej i etyki na teorie oparte na celach, obowiązku i właśnie na prawach (Dworkin 1998, 277-332). Systematyczne rozwinięcie tej myśli na poziomie metaetycznym przedstawili J. L. Mackie i Joseph Raz (Mackie 1992; Raz 1992), a jej najbardziej znaną realizacją jest koncepcja Roberta Nozicka (Nozick 1999). Autor ten wychodzi od kilku podstawowych tez, mających charakter aksjomatów sformułowanych w języku praw, a następnie rozwija ich konsekwencje. Dla teorii etycznych opartych na prawach moralne prawo podmiotowe jest pojęciem podstawowym, niesprowadzalnym do innych pojęć prostych (np. obowiązku) (Brandt 1996, 734-770).

Tym, co jest charakterystyczne dla etycznej teorii praw jest jej niesystemowy charakter. Wraz z indywidualizmem prawa podmiotowe zakładają różnie rozumiany pluralizm (rzeczywistości społecznej, wartościowych dóbr, celów jednostek). Prawa mają chronić ten pluralizm przez wyznaczanie ostrych granic autonomii jednostki. Cele i wartości jednostek nie sumują się w prosty sposób, nie dadzą się uporządkować przez naczelny rozum, a konflikty między nimi są chroniczne (Polanowska-Sygulska 2008). 
Wielu autorów, znanych w Polsce przede wszystkim jako autorzy z obszaru filozofii prawa, w dyskursie anglosaskim funkcjonuje również jako etycy (przede wszystkim Ronald Dworkin i John Finnis). Należy więc pamiętać, że chociaż prawa podmiotowe rozwijane są w oparciu o język i metaforykę prawniczą, to ich prawnicza interpretacja nie musi być wcale dominująca (Buckle 2000).

\section{PODSUMOWANIE}

W Polsce filozoficzna dyskusja nad prawami podmiotowymi rozbita jest na wiele obszarów szczegółowych, bez zauważania pola wspólnego. W ramach podsumowania wymienię najważniejsze problemy i spory filozoficzne, które można włączyć w obszar zainteresowania filozofii praw podmiotowych:

- Jakie są ontologiczne podstawy praw podmiotowych?

- Jakie jest źródło praw?

- Kto jest podmiotem praw?

- Do czego można mieć prawo?

- Czy istotą praw są wola czy interes?

- W jaki sposób uzasadniane są prawa? Jaka jest moc legitymizacyjna praw?

- Czy istnieja prawa niezbywalne, absolutne lub uniwersalnie ważne?

- Czy prawa podmiotowe są zrelatywizowane kulturowo i historycznie?

- Jaka jest rola praw podmiotowych w zmianie społecznej?

- Czy prawa emancypują jednostki? Czy w związku z tym w konieczny sposób osłabiają wspólnoty?

- Jakie jest miejsce praw podmiotowych w sporze między indywidualizmem a koncepcjami kolektywistycznymi?

- Czy prawa mają własną dynamikę rozwoju, np. czy ich zakres się ciągle poszerza?

- W jaki sposób prawa zmieniają strukturę władzy w społeczeństwie?

- Czy prawa podmiotowe są pojęciem podstawowym, które może zorganizować pewien rodzaj dyskursu (prawo, politykę, etykę)?

- Jak rozwiązywać konflikty praw?

- Czy prawa prowadzą do konfliktów, czy też potrafią je również łagodzić i rozwiązywać?

- Jak prawa podmiotowe mają się do systemów normatywnych (prawnych, moralnych)? Czy prawa mogą tworzyć system?

- Czy prawa podmiotowe są pustą formą instytucjonalną, czy zawierają pewne immanentne treści (np. wartości liberalne, zachodnie)?

- Jaka jest relacja między prawami podmiotowymi a użytecznością?

- Jaka jest relacja między prawami a interesami?

- Czy istnieja prawa niepozytywne? 


\section{BIBLIOGRAFIA}

Alexy, Robert. 2010. Teoria praw podstawowych. Tł. Bożena Kwiatkowska, Jerzy Zajadło. Warszawa: Wydawnictwo Sejmowe.

Almond, Brenda. 2000. „Prawa”. W Przewodnik po etyce. Red. Peter Singer. Tł. Paweł Łuków. 303-314. Warszawa: Książka i Wiedza.

Bator, Andrzej (red.). 2008. Wprowadzenie do nauk prawnych. Leksykon tematyczny. Warszawa: LexisNexis.

Beamish, Richard J., Chrys-Ellen M. Neville. 2006. "Ecosystem Bill of Rights". W Toward Principled Oceans Governance. Australian and Canadian Approaches and Challenges. Eds. Donald R. Rothwell, David L. VanderZwaag. 233. Abingdon, NY: Routledge.

Bentham, Jeremy. 1973. "A Critical Examination of the Declaration of Rights". W Bentham's Political Thought. Ed. Bhikhu Parekh. 257-290. London: Croom Helm.

Bierć, Andrzej. 2012. Zarys prawa prywatnego. Część ogólna. Warszawa: Lex a Wolters Kluwer business.

Błachut, Michał. 2002. „Pojęcie prawa podmiotowego we współczesnej liberalnej filozofii prawa”. Ruch Prawniczy, Ekonomiczny i Socjologiczny 64 (1): 35-52.

Borucka-Arctowa, Maria. 1957. Prawo natury jako ideologia antyfeudalna. Warszawa: PWN.

Brandt, Richard B. 1996. Etyka. Zagadnienia etyki normatywnej i metaetyki. Tł. Barbara Stanosz. Warszawa: PWN.

Buckle, Stephen. 2000. „Prawo naturalne”. W Przewodnik po etyce. Red. Peter Singer. Tł. Paweł Łuków. 199-213. Warszawa: Książka i Wiedza.

Campbell, Kenneth. 2001. "Legal Rights". W Stanford Encyclopedia of Philosophy. Ed. Edward N. Zalta. Stanford: Stanford University Press.

Coyle, Marcia. 2013. The Roberts Court. The Struggle for the Constitution. New York: Simon \& Schuster.

Dworkin, Ronald. 1998. Biorac prawa poważnie. Tł. Tomasz Kowalski. Warszawa: Wydawnictwo Naukowe PWN.

Edmundson, William A. 2004. An Introduction to Rights. Cambridge: Cambridge University Press.

Etzioni, Amitai. 1994. Rights and the Common Good: The Communitarian Perspective. New York: St. Martin's Press.

Finnis, John. 2001. Prawo naturalne i uprawnienia naturalne. Tł. Karolina Lossman. Warszawa: Dom Wydawniczy ABC.

Habermas, Jürgen. 2005. Faktyczność i obowiqzywanie. Tł. Adam Romaniuk, Robert Marszałek. Warszawa: Scholar.

Harel, Alon. 2005. "Theories of Rights". W The Blackwell Guide to the Philosophy of Law and Legal Theory. Eds. Martin P. Golding, William A. Edmundson. 191-206. Malden-OxfordCarlton: Blackwell Publishing.

Hart, Herbert L. A. 1998. Pojęcie prawa. Tł. Jan Woleński. Warszawa: Wydawnictwo Naukowe PWN.

Hart, Herbert L. A. 2001a. „Pomiędzy użytecznością a uprawnieniami”. W Eseje z filozofii prawa. Tł. i wstęp Jan Woleński. 198-223. Warszawa: Dom Wydawniczy ABC.

Hart, Herbert L. A. 2001b. „Utylitaryzm i prawa podmiotowe”. W Eseje z filozofii prawa. Tł. i wstęp Jan Woleński. 181-197. Warszawa: Dom Wydawniczy ABC.

Hilbink, Thomas. 2009. "The Right's Revolution?: Conservatism and the Meaning of Rights in Modern America”. Studies in Law, Politics and Society 48: 43-68.

Hohfeld, Wesley N. 1923. Fundamental Legal Conceptions as Applied in Judicial Reasoning and Other Legal Essays. New Haven: Yale University Press. 
Hołówka, Jacek. 2000. Etyka w działaniu. Warszawa: Prószyński i S-ka.

Jakimowicz, Wojciech. 2002. Publiczne prawa podmiotowe. Kraków: Zakamycze.

Kennedy, Duncan. 1997. A Critique of Adjudication (Fin de Siècle). Cambridge, MA-London: Harvard University Press.

Kojder, Andrzej, Zbigniew Cywiński (red.). 2014. Socjologia prawa. Główne problemy i postacie. Warszawa: Wydawnictwo Uniwersytetu Warszawskiego.

Kowalski, Jerzy, Wojciech Lamentowicz, Piotr Winczorek. 1981. Teoria państwa i prawa. Warszawa: PWN.

Lang, Wiesław, Jerzy Wróblewski, Sylwester Zawadzki. 1980. Teoria państwa i prawa. Warszawa: PWN.

Leżoń, A. (red.). 1977. O prawach rzeczywistych i pozornych. Tł. Ryszard Czerwiński, Stefan Gajda. Warszawa: Książka i Wiedza.

Mackie, John L. 1992. "Can There Be a Right-Based Moral Theory?” W Theories of Rights. Ed. Jeremy Waldron. 168-181. Oxford: Oxford University Press.

Marks, Karol, Fryderyk Engels. 1962. „W kwestii żydowskiej”. W Dzieła. T. 1. Warszawa: Książka i Wiedza.

Marshall, Thomas H. 1997. "Class, Citizenship and Social Development". W Welfare State. Historia, kryzys i przyszłość nowoczesnego państwa opiekuńczego. Red. Kazimierz W. Frieske, Paweł Poławski. 28-41. Warszawa: Instytut Socjologii Uniwersytetu Warszawskiego.

McGrade, Arthur Stephen. 1980. "Ockham and the Birth of Individual Rights". W Authority and Power. Studies on Medieval Law and Government Presented to Walter Ullmann on His Seventieth Birthday. Ed. Brian Tierney, Peter Linehan. 149-165. Cambridge: Cambridge University Press.

Nickel, James. 2003. "Human Rights". W Stanford Encyclopedia of Philosophy. Stanford: Stanford University Press.

Nozick, Robert. 1999. Anarchia, Państwo, Utopia. Tł. Paweł Maciejko, Michał Szczubiałka. Warszawa: Aletheia.

Opałek, Kazimierz. 1957. Prawo podmiotowe. Studium teorii prawa. Warszawa: PWN.

Osiatyński, Wiktor. 2011. Prawa człowieka i ich granice. Tł. Sergiusz Kowalski. Kraków: Znak.

Piechowiak, Marek. 1999. Filozofia praw człowieka. Prawa człowieka wświetle ich międzynarodowej ochrony. Lublin: Towarzystwo Naukowe Katolickiego Uniwersytetu Lubelskiego Jana Pawła II.

Polanowska-Sygulska, Beata. 2008. Pluralizm wartości i jego implikacje w filozofii prawa. Kraków: Księgarnia Akademicka - Ośrodek Myśli Politycznej.

Primus, Richard A. 2004. The American Language of Rights. Cambridge: Cambridge University Press.

Przybyszewski, Krzysztof. 2010. Prawa człowieka w kontekstach kulturowych. Poznań: Wydawnictwo Naukowe Instytutu Filozofii UAM.

Pyziak-Szafnicka, Małgorzata. 2007. „Prawo podmiotowe”. W System prawa prywatnego. T. 1. Prawo cywilne - część ogólna. Red. Marek Safjan. 671-829. Warszawa: C.H. Beck - Instytut Nauk Prawnych PAN.

Raburski, Tomasz. 2012. Autonomizacja prawa wobec państwa w sferze międzynarodowej. Poznań: Wydawnictwo Naukowe Instytutu Filozofii UAM.

Raburski, Tomasz. 2014. "Amerykański język praw podmiotowych a demokracja”. Filozofia Publiczna i Edukacja Demokratyczna 3 (1): 59-76.

Rawls, John. 2001. Prawo ludów. Tł. Michał Kozłowski. Warszawa: Aletheia.

Rawls, John. 2009. Teoria sprawiedliwości. Tł. Maciej Panufnik, Jarosław Pasek, Adam Romaniuk. Warszawa: PWN. 
Raz, Joseph. 1992. "Right-Based Moralities". W Theories of Rights. Ed. Jeremy Waldron. Oxford: Oxford University Press.

Reid, Charles jr. 1998. "The Medieval Origins of the Western Natural Rights Tradition: The Achievement of Brian Tierney". Cornell Law Review 83: 437-463.

Rosenberg, Gerald N. 1991. The Hollow Hope. Can Courts Bring About Social Change?. ChicagoLondon: The University of Chicago Press.

Scheingold, Stuart A. 2004. The Politics of Rights. Lawyers, Public Policy, and Political Change. Ann Arbor: The University of Michigan Press.

Solomon, Ty. 2006. "Norms and Human Rights in International Relations". Political Studies Review 4 (1): 36-47.

Stelmachowski, Andrzej. 1998. Zarys teorii prawa cywilnego. Warszawa: Wydawnictwo Naukowe PWN.

Strauss, Leo. 1983. "Natural Law". W Studies in Platonic Political Philosophy. 137-146. Chicago: University of Chicago Press.

Strauss, Leo. 2012. „Prawo naturalne”. W Jerozolima i Ateny oraz inne eseje z filozofii politycznej. Tł. Ryszard Mordarski. 136-147. Kęty: Wydawnictwo Marek Derewiecki.

Vardy, Peter, Paul Grosch. 1994. Etyka. Poglady i problemy. Tł. Jerzy Łoziński. Poznań: Zysk i S-ka.

Voegelin, Eric. 1978. "What Is Right by Nature". W Anamnesis. 55-70. Notre Dame, IN: University of Notre Dame Press.

Waldron, Jeremy (ed.). 1992. Theories of Rights. Oxford: Oxford University Press.

Wenar, Leif. 2005. "Rights". W Stanford Encyclopedia of Philosophy. Ed. Edward N. Zalta. Stanford: Stanford University Press.

Wojtczak, Sylwia. 2011. „Wpływ piśmiennictwa anglojęzycznego z zakresu prawoznawstwa na zmianę paradygmatu polskiej teorii prawa”. W Czy koniec teorii prawa? Red. Paweł Jabłoński. 81-91. Wrocław: Wydawnictwo Uniwersytetu Wrocławskiego.

Wronkowska, Sławomira. 1973. Analiza pojęcia prawa podmiotowego. Poznań: Wydawnictwo Naukowe UAM.

Wronkowska, Sławomira, Zygmunt Ziembiński. 2001. Zarys teorii prawa. Poznań: Ars Boni et Aequi.

Zajadło, Jerzy. 2004. „Filozoficzne problemy ochrony praw jednostki”. W Ochrona praw jednostki. Red. Zdzisław Brodecki. 23-37. Warszawa: LexisNexis.

Zajadło, Jerzy (red.). 2007. Leksykon wspótczesnej teorii i filozofii prawa. Warszawa: C.H. Beck. Ziembiński, Zygmunt. 1980. Problemy podstawowe prawoznawstwa. Warszawa: PWN.

Zirk-Sadowski, Marek. 2000. Wprowadzenie do filozofii prawa. Kraków: Kantor Wydawniczy Zakamycze.

\section{Tomasz Raburski}

\section{THE PHILOSOPHY OF RIGHTS}

\footnotetext{
Abstract. Rights are one of the fundamental concepts in philosophy of law, ethics, and political philosophy. However, in Polish language the general research on rights has been neglected. Most of the scholars are concerned with the specific kinds of rights (e.g. human rights, constitutional rights) and not rights as a basic philosophical concept. This article investigates the differences between Polish and English theoretical discourses on rights. It stresses the philosophical importance of this concepts and outlines the crucial issues that have to addressed.

Keywords: rights, human rights, politics of rights, ethics of rights, law and morality, Polish legal theory.
} 